\title{
BCRP expression in schwannoma, plexiform neurofibroma and MPNST
}

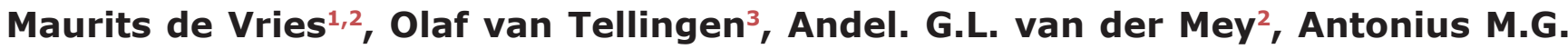 \\ Bunt $^{4}$, Inge Briaire-de Bruijn ${ }^{1}$ and Pancras C.W. Hogendoorn ${ }^{1}$ \\ ${ }^{1}$ Department of Pathology, Leiden University Medical Center, Leiden, The Netherlands \\ ${ }^{2}$ Department of Otolaryngology, Leiden University Medical Center, Leiden, The Netherlands \\ ${ }^{3}$ Division of Pharmacology/Mouse Cancer Center, The Netherlands Cancer Institute, Amsterdam, The Netherlands \\ ${ }^{4}$ IzumiBiosciences, Inc., Lexington, USA \\ Correspondence to: Maurits de Vries, email:w.m.de_vries@lumc.nl \\ Keywords: BCRP, schwannoma, neurofibroma, drug resistance, MPNST \\ Received: March 17, $2017 \quad$ Accepted: June 17, $2017 \quad$ Published: September 16, 2017 \\ Copyright: de Vries et al. This is an open-access article distributed under the terms of the Creative Commons Attribution License \\ 3.0 (CC BY 3.0), which permits unrestricted use, distribution, and reproduction in any medium, provided the original author and \\ source are credited.
}

\section{ABSTRACT}

Background: peripheral nerve sheath tumors comprise a broad spectrum of neoplasms. Vestibular schwannomas and plexiform neurofibromas are symptomatic albeit benign, but a subset of the latter pre-malignant lesions will transform to malignant peripheral nerve sheath tumors (MPNST). Surgery and radiotherapy are the primary strategies to treat these tumors. Intrinsic resistance to drug therapy characterizes all three tumor subtypes. The breast cancer resistance protein BCRP is a transmembrane efflux transporter considered to play a key role in various biological barriers such as the blood brain barrier. At the same time it is associated with drug resistance in various tumors. Its potential role in drug resistant tumors of the peripheral nervous system is largely unknown.

Objective: to assess if BCRP is expressed in vestibular schwannomas, plexiform neurofibromas and MPNST.

Material and methods: immunohistochemical staining for BCRP was performed on a tissue microarray composed out of 22 vestibular schwannomas, 10 plexiform neurofibromas and 18 MPNSTs.

Results: sixteen out of twenty-two vestibular schwannomas (73\%), nine out of ten plexiform neurofibromas ( $90 \%)$ and six out of eighteen MPNST (33\%) expressed BCRP in the vasculature. Tumor cells were negative.

Conclusion: BCRP is present in the vasculature of vestibular schwannomas, plexiform neurofibromas and MPSNT. Therefore, it may reduce the drug exposure of underlying tumor tissues and potentially cause failure of drug therapy.

\section{INTRODUCTION}

Peripheral nerve sheath tumors (PNST) are relatively common neoplasm's that comprise a broad spectrum of different subtypes. Most of these tumors are histologically benign such as schwannomas and neurofibromas $[1,2]$. Next to these benign tumors there is a subset of malignant lesions like the malignant peripheral nerve sheath tumors (MPNST) [3, 4]. Neurofibromas, MPNST and schwannomas are examples of PNST that occur either sporadically or as part of hereditary neurocutaneous diseases like neurofibromatosis type I (NF1) and neurofibromatosis type II (NF2) respectively. Both these disorders seem to result from the inactivation of a classic tumor suppressor gene. Neurofibromas and MPNST show loss of $N F 1$ expression. The $N F 1$ gene is located on chromosome 17q11.2. and encodes the tumor suppressor protein neurofibromin [5]. NF1 is caused by germline mutations in NFI but there are also mosaic forms of this disease [6]. MPNST or plexiform neurofibromas 
without other symptoms of NF1, i.e. sproradic tumors, are probably caused by somatic mosaicism for an NF1 mutation. A similar situation is seen in NF2. NF2 is caused by biallilec inactivation of the $N F 2$ gene, located on chromosome 22q11, which encodes the tumor suppressor protein merlin [7]. Bilateral vestibular schwannomas are pathognomonic for this rare disease. However, most vestibular schwannomas occur as sporadic unilateral tumors [8].

Schwannomas occur in a wide range of anatomical sites, including the subcutaneous tissues of the distal extremities and the head and neck region. Schwannomas in the head and neck region have a predilection to derive from the vestibular portion of the eighth cranial nerve, better known as vestibular schwannomas (VS). Schwannomas are neoplastic proliferations that exclusively comprise Shwann cells while neurofibromas contain multiple cell types such as perineurial cells, fibroblasts and to a lesser extent Schwann cells [1, 911] There are two types of neurofibromas: dermal and plexiform. Plexiform neurofibromas are strongly related to NF1, affecting $20 \%$ to $40 \%$ of patients suffering from this condition $[12,13]$. These tumors often occur in the head, skull base, or neck but also manifest themselves on the trunk and limbs. Plexiform neurofibromas have the potential to transform into MPNST. However, not all MPNST develop from pre-existing neurofibromas, as approximately half of all MPNST arise sporadically without a known precursor [14].

These different types of tumors require different types of therapy. To date surgical excision is the only effective treatment for plexiform neurofibromas, but recent literature demonstrated that targets for pharmacological treatment are emerging $[15,16]$. Therapeutic management of (vestibular) schwannomas consist of surgery or radiotherapy and pharmacological treatment options were recently tested as well [17]. Although there are promising results in individual NF2 patients treated with targeted therapy there are also reports indicating drug resistance in these tumors [18]. A similar situation exists in MPNST. The triad of surgery, radiotherapy and multiagent chemotherapy is applied to these tumors as well. Despite promising reports on for instance (neoadjuvant) doxorubicin-ifosfamide treatment regimens, these tumors are often characterized by a highly aggressive behavior and resistance to multidrug therapy, resulting in poor longterm survival rates [19-21]. In short, despite the different therapies that are applied to these PNST one of their common dominators is the fact that they show a certain degree of drug resistance.

Acquired and/or innate drug resistance of tumor cells is a common phenomenon and a major hurdle to effective chemotherapeutic intervention. An important mechanism contributing to drug resistance concerns the expression of ATP binding cassette (ABC) transporter proteins that are capable of extruding drugs from tumors [22]. These energy-dependent transmembrane proteins transport a wide range of substrates, including many anticancer drugs, across cell membranes [23-27]. So far 49 genes have been identified to encode for members of the ABC transporter family [28], but only a subset of these is involved in drug resistance. Of these drug transporters $\mathrm{ABCB} 1$ (P-gp) and ABCG2 (BCRP) are the most extensively studied. They were first discovered in tumor cells [29, 30], but are also expressed at the apical membranes of epithelial cells in biological barrier tissues such as in the intestines, kidneys and liver and have an important role in the clearance of xenobiotics from the body [23]. In addition, they are expressed in specialized endothelial cells that form the blood-brain, blood-testis and blood-placenta barriers where they help to limit the exposure of the underlying tissues (brain, testis and fetus) to xenobiotics [31-33]. Besides efflux transporters, these specialized endothelial cells also present other barrier properties, such as tight junctions and lack of fenestrations that limit para-cellular entry of drugs. In the brain, the surrounding glial cells (astrocytes, pericytes) govern the expression of these barrier markers in these endothelial cells. The bloodbrain barrier (BBB) may thereby "protect" tumor cells that reside within the central nervous system [34]. Similar to the situation in the brain, tumors originating from the peripheral nerve sheath may be protected by the so called blood-nerve-barrier (BNB). Our hypothesis is that the blood-nerve-barrier might hinder drugs from reaching their target cells in peripheral nerve sheath tumors, thereby contributing to drug resistance (Figure 1). The three tumor types we included in this analysis were selected because all of them originate from the peripheral nerve sheath and, as mentioned earlier, each of them are characterized by some form of drug resistance. The BNB is located in microvasculature of the endoneurium and the inner most layers of the perineurium [35] and there are reports that, analogous to the situation at the BBB, the BNB contains members of the ABC transporter family such as BCRP and $\mathrm{P}-\mathrm{gb}[36,37]$. Apart from the concept of protection by the $\mathrm{BNB}$, these tumors may also be drug resistant because the tumor cells themselves express ABC drug transporters. Since its discovery, BCRP expression has been observed in several types of tumors [38-47] and elevated expression levels of this transporter have been correlated with poor prognosis in a number of studies [48-50]. Moreover, the expression of BCRP in tumor cells has been associated with a rare subset of so-called cancer stem cells, similar to the expression of BCRP in normal stem cells [51, 52]. Consequently, the expression of BCRP both in tumor blood vessels or in tumor cells can mediate drug resistance.

The aim of this study was to assess the presence and localization of BCRP in peripheral nerve sheath tumors. We investigated the expression pattern of BCRP in twenty-two sporadic vestibular schwannomas, ten plexiform neurofibromas and eighteen MPNST using an immunohistochemical assay performed on a tissue microarray (TMA) composed of these tumors. We used 
TMA technology because it provides the advantage of simultaneously analyzing a large panel of tumors with a high degree of experimental standardization [53]. Is has also been shown that the clinico-pathological findings obtained by this technique are highly representative of their donor tissues [54]. The results of our analysis show that BCRP is expressed in all three of these tumor types. This observation indicates that BCRP might reduce drug accumulation in these peripheral nerve sheath tumors thus creating a hurdle to effective drug treatment.

\section{RESULTS}

The results from this immunohistochemical, tissue micro array based study indicate the presence of BCRP in the microvascular endothelium of MPNST, plexiform neurofibromas and vestibular schwannomas (Figure 2). Six out of the eighteen MPNST samples showed vascular BCRP expression. Two of the positive specimens were NF1 related and the other four were sporadic tumors. Tumor cells were negative for BCRP. One of the studied MPNSTs was a recurrent tumor and matched with another specimen in this study. In both cases, the vasculature of these samples was BCRP negative. None of the MPNST patients received chemotherapy prior to resection. The vasculature of nine out of ten plexiform neurofibroma samples was BCRP positive as well as the vasculature of sixteen of the twenty-two schwannomas. Two separate plexiform neurofibroma samples originated from the same NF1 patient and both these tumors had BCRP positive vasculature. Unfortunately, the analyzability of some of the MPNST tumor specimens on the TMA slide

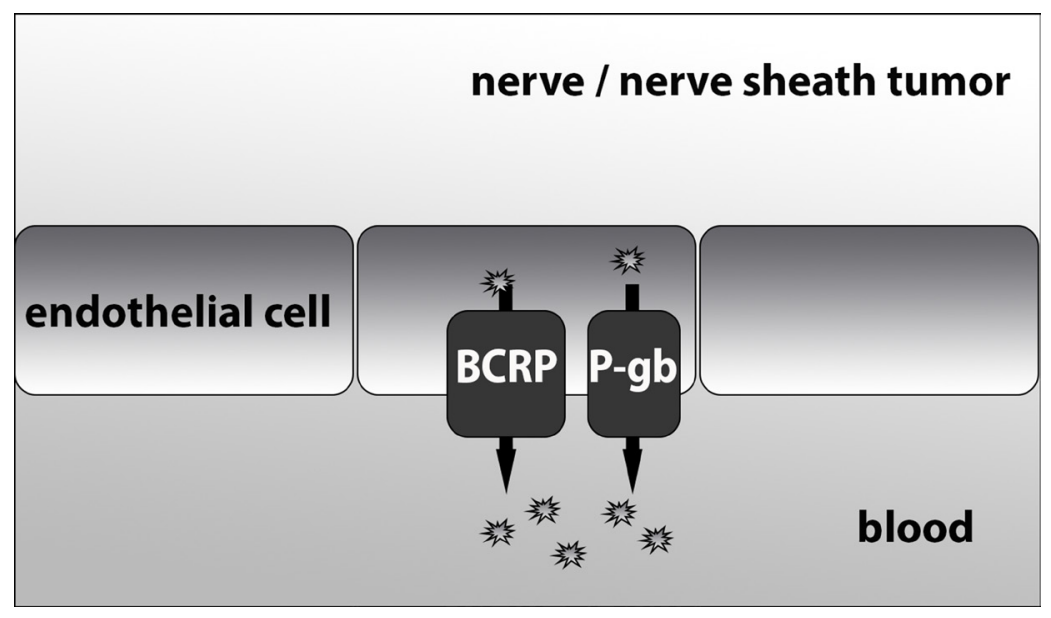

Figure 1: A mechanistic figure of the proposed function of BCRP and P-gb at the blood-nerve-barrier.

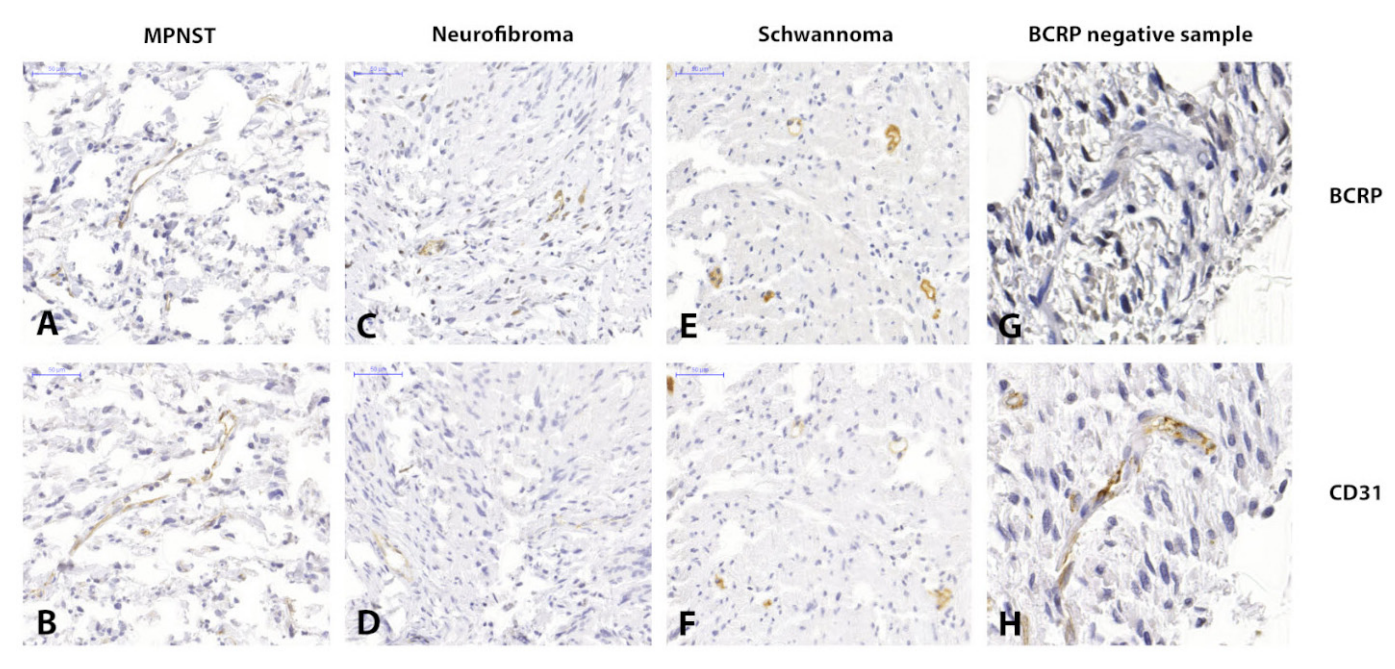

Figure 2: Immunohistochemistry images showing clear BCRP and CD31 positivity in the microvascular epithelium of MPNST(A and B), plexiform neurofibroma $(\mathbf{C}$ and $\mathbf{D})$ and vestibular schwannoma $(\mathbf{E}$ and $\mathbf{F})$ respectively. Images $(\mathbf{G}$ and $\mathbf{H})$ show a CD31 positive yet BCRP negative sample of a vestibular schwannoma. 
was impaired due to necrosis. We found that in four out of eighteen MPNST cases one or two specimens showed intrinsic tumor necrosis making them unsuitable for microscopic analysis. Nevertheless, at least one of the three specimens of these tumors contained representative tumor tissue. Therefore it was still possible to perform adequate microscopic analysis on tissue from all the tumors in the analysis. Of these four MPNST one was scored positive for BCRP and the other three were scored negative.

\section{DISCUSSION}

Present treatment of peripheral nerve sheath tumors is mainly a surgical matter. The unraveling of the underlying molecular pathologies and the ongoing development of new therapeutic agents may provide potentially effective drugs as an alternative- or concomitant therapeutic strategy. Unfortunately, however, the occurrence of innate or acquired drug resistance of tumors is a common event. Drug resistance is a frequently encountered problem in MPNST, but it is also observed in benign or precursor lesions. Multidrug resistance is a complex phenomenon and frequently multifactorial. One important reason is impaired drug delivery to the target tissues because of the expression of drug efflux proteins in the (micro) vasculature of tumor tissues or because of expression of these proteins by tumor cells themselves. In central nervous system (CNS) tissues, the restricted entry is due to drug transporters located at the interface between the blood and the brain (the BBB). A similar situation may be present at the interface between blood and peripheral nerves, but this has not been well established yet. The most extensively studied efflux transporters of the BBB are P-gp (ABCB1) [55] and BCRP (ABCG2) [56]. Together, these two efflux transporters team up to restrict the CNS penetration of a wide range of substrates including many potentially useful drugs [56-59]. In this study, we have investigated the expression of BCRP in tumors of the peripheral nervous system. Based on our results it is not entirely clear if the vascular BCRP expression we observed in a selection of the investigated tumors is a specific characteristic of these tumors, or if it is a remaining part of the blood-nervebarrier. Dahin et al [60] identified BCRP expression in retinal nerve fibers suggesting that BCRP is part of the blood-nerve-barrier that protects retinal nerve fibers from injury by removing intracellular toxins and xenobiotics. A contradictory observation was made by Huang et al [61]. They investigated BCRP and P-gp in peripheral nerves using a tissue distribution assay on rats but did not find a difference in drug distribution between wild type- or BCRP/P-gp knock out rats. However, in the Huang study the Abcg2 KO had little effect on the brain distribution of known BCRP substrate drugs and these findings are at odds with other $\mathrm{ABC} \mathrm{KO}$ studies and have not been replicated independently since $[37,62,63]$. Furthermore, they are in stark contrast with multi drug resistance observed in clinical studies in NF1 patients with known P-gp and/or BCRP substrate drugs [15, 16, 64-66]. Similarly, prior studies in MPNST confirmed the presence of drug resistant sarcoma stem cells $[67,68]$ and the P-gp and BCRP efflux pumps [47, 50, 69, 70], while drug trials in MPNST patients have not improved outcomes [50, 71] Our findings provide a rationale to further study the hypothesis that endothelial BCRP expression may be part of the reason why drug therapy of PNST often fails [47]. If this hypothesis is correct it could mean that inhibition of BCRP may aid in rendering these tumors more susceptible to drug therapy. A potential strategy to achieve this is to co-administer elacridar, a potent, selective inhibitor of both P-gp and BCRP with molecularly targeted drugs to enhance drug levels in diseased neural tissues and improve outcomes as has been observed in animal models of other pump-protected diseases [34, 72-82].

In conclusion, our results demonstrate the expression of BCRP in the vascular endothelium in a substantial fraction of MPNST, plexiform neurofibromas and sporadic vestibular schwannomas. Similar to CNS tumors, the presence of BCRP, and perhaps other members of the $\mathrm{ABC}$ efflux transporter family, may reduce the drug exposure of underlying tumor tissues and mediate resistance to drug therapy.

\section{MATERIALS AND METHODS}

\section{Patients}

The cases included in this study were retrospectively selected from the files of the bone- and soft tissue tumor database at the department of Pathology of the Leiden University Medical Center, Leiden the Netherlands. Tumor specimens were obtained from patients surgically treated for their tumors between January 1999 and December 2012. Formalin-fixed paraffin-embedded samples of twenty-two sporadic vestibular schwannomas, ten plexiform neurofibromas and eighteen MPNST were selected. Of these selected tumors two separate plexiform neurofibromas originated from the same patient and one MPNST was a recurrence of a primary tumor included in this analysis as well. Surgery was performed at the departments of Neurosurgery, Otolaryngology, Orthopedic surgery and General surgery of the Leiden University Medical Center. In each case the diagnosis was made according to the WHO classification of soft tissue tumors [83]. All tumor samples were handled in a coded fashion and all procedures were performed according to the ethical guidelines of the Code for Proper Secondary Use of Human Tissue in The Netherlands (Dutch Federation of Medical Scientific Societies). Additional clinicopathological data are shown in Supplementary Table 1 . 


\section{Tissue microarray (TMA) preparation}

Preparation of the TMAs was performed at the department of pathology of the Leiden University Medical Center. TMAs were constructed from $1 \mathrm{~mm}$ cores of all tumor samples using a TMA Master (3DHISTECH Ltd, Budapest, Hungary). Per tumor three randomly selected cores were included in the TMA in order to compensate for intra-tumoral heterogeneity. Normal colon, tonsil, placenta, prostate and spleen tissue together with mamma carcinoma were used to serve as internal controls and points of orientation. In line with data provided by the manufacturer we found high BCRP expression in placenta and low expression in colon tissue.

\section{Immunohistochemistry (IHC)}

Immunohistochemical reactions were performed according to standard laboratory methods [84]. In brief, heatinduced antigen retrieval was performed after dewaxing and rehydration, followed by blocking of endogenous peroxidase with $3 \% \mathrm{H}_{2} \mathrm{O}_{2}$ in methanol. Incubation with the primary antibodies BCRP (Abcam; ab24115) and CD31 (Abcam; ab28364) was overnight. Subsequently, CD31 sections were conjugated with Labelled PolymerHRPAnti-Rabbit Envision (DakoCytomation; K4005) while conjugation of the BCRP sections was performed with Goat- $\alpha$-Rat-Bio (Santa Cruz; SC-2041) and Streptavidin/ HRP (DakoCytomation; P0397) respectively. Visualization was carried out with a diaminobenzidine solution. All washing procedures were conducted in phosphate-buffered saline. Slides were counterstained with haematoxylin.

\section{Microscopic analysis}

After staining the TMA was scanned using a Pannoramic MIDI Digital Slide Scanner (3DHISTECH Ltd, Budapest, Hungary). Analysis of the digital slides took place with Pannoramic Viewer software version 1.15.3. Scoring was performed by two observers who were unaware of the clinico-pathological data. Staining of tumor specimens was classified as either positive or negative. Differently assessed cases were discussed to reach consistent scoring results.

\section{Abbreviations}

ABC: ATP binding cassette; ABCB1: ATP-binding cassette sub-family B member 1; ABCG2: ATP-binding cassette sub-family $\mathrm{G}$ member 2; BBB: Blood-brainbarrier; BCRP: Breast Cancer Resistance Protein; BNB: Blood-nerve-barrier; MPNST: Malignant peripheral nerve sheath tumors; NF 1: Neurofibromatosis type I; NF 2: Neurofibromatosis type II; P-gb: permeability glycoprotein; PNST: Peripheral nerve sheath tumors; TMA: Tissue micro array; VS: Vestibular schwannomas.

\section{CONFLICTS OF INTEREST}

No potential conflicts of interest were disclosed.

\section{FUNDING}

This research received no specific grant from any funding agency in the public, commercial, or not-for-profit sector.

\section{REFERENCES}

1. Louis DN, Ohgaki H, Wiestler OD, Cavenee WK, Burger PC, Jouvet A, Scheithauer BW, Kleihues P. The 2007 WHO classification of tumours of the central nervous system. Acta Neuropathol. 2007; 114: 97-109. https://doi.org/10.1007/ s00401-007-0243-4.

2. Fletcher CDM, Bridge JA, Hogendoorn PCW, Mertens F. (2013). WHO classification of tumours of soft tissue and bone. (France: Lyon: IARC Press, 2013.).

3. Ferner RE, O'Doherty MJ. Neurofibroma and schwannoma. CurrOpinNeurol. 2002; 15: 679-84. https://doi. org/10.1097/01.wco.0000044763.39452.aa.

4. Rodriguez FJ, Folpe AL, Giannini C, Perry A. Pathology of peripheral nerve sheath tumors: diagnostic overview and update on selected diagnostic problems. Acta Neuropathol. 2012; 123: 295-319. https://doi.org/10.1007/ s00401-012-0954-z.

5. Abramowicz A, Gos M. Neurofibromin in neurofibromatosis type 1 - mutations in NF1gene as a cause of disease. DevPeriodMed. 2014; 18: 297-306.

6. Kehrer-Sawatzki H, Cooper DN. Mosaicism in sporadic neurofibromatosis type 1 : variations on a theme common to other hereditary cancer syndromes? J Med Genet. 2008; 45: 622-31. https://doi.org/10.1136/jmg.2008.059329.

7. Sainz J, Huynh DP, Figueroa K, Ragge NK, Baser ME, Pulst SM. Mutations of the neurofibromatosis type 2 gene and lack of the gene product in vestibular schwannomas. HumMolGenet. 1994; 3: 885-91.

8. Evans DG, Moran A, King A, Saeed S, Gurusinghe $\mathrm{N}$, Ramsden R. Incidence of vestibular schwannoma and neurofibromatosis 2 in the North West of England over a 10-year period: higher incidence than previously thought. OtolNeurotol. 2005; 26: 93-7. https://doi. org/00129492-200501000-00016.

9. Lassmann H, Jurecka W, Lassmann G, Gebhart W, Matras H, Watzek G. Different types of benign nerve sheath tumors. Light microscopy, electron microscopy and autoradiography. Virchows ArchA PatholAnatHistol. 1977; 375: 197-210.

10. Ushigome S, Takakuwa T, Hyuga M, Tadokoro M, Shinagawa T. Perineurial cell tumor and the significance of 
the perineurial cells in neurofibroma. Acta PatholJpn. 1986; 36: $973-87$.

11. Woodruff JM. The pathology and treatment of peripheral nerve tumors and tumor-like conditions. CA Cancer J Clin. 1993; 43: 290-308.

12. Tonsgard JH, Kwak SM, Short MP, Dachman AH. CT imaging in adults with neurofibromatosis-1: frequent asymptomatic plexiform lesions. Neurology. 1998; 50: 1755-60.

13. Huson SM, Harper PS, Compston DA. Von Recklinghausen neurofibromatosis. A clinical and population study in southeast Wales. Brain. 1988; 111 ( Pt 6): 1355-81.

14. Subramanian S, Thayanithy V, West RB, Lee CH, Beck AH, Zhu S, Downs-Kelly E, Montgomery K, Goldblum JR, Hogendoorn PC, Corless CL, Oliveira AM, Dry SM, et al. Genome-wide transcriptome analyses reveal p53 inactivation mediated loss of miR-34a expression in malignant peripheral nerve sheath tumours. JPathol. 2010; 220: 58-70. https://doi.org/10.1002/path.2633.

15. Weiss B, Widemann BC, Wolters P, Dombi E, Vinks A, Cantor A, Perentesis J, Schorry E, Ullrich N, Gutmann DH, Tonsgard J, Viskochil D, Korf B, et al. Sirolimus for progressive neurofibromatosis type 1-associated plexiform neurofibromas: a neurofibromatosis Clinical Trials Consortium phase II study. NeuroOncol. 2015; 17: 596-603.

16. Dombi E, Baldwin A, Marcus LJ, Fisher MJ, Weiss B, Kim A, Whitcomb P, Martin S, Aschbacher-Smith LE, Rizvi TA, Wu J, Ershler R, Wolters P, et al. Activity of Selumetinib in Neurofibromatosis Type 1-Related Plexiform Neurofibromas. N Engl J Med. 2016; 375: 2550-60. https:// doi.org/10.1056/NEJMoa1605943.

17. de Vries M, van der Mey AG, Hogendoorn PC. Tumor Biology of Vestibular Schwannoma: A Review of Experimental Data on the Determinants of Tumor Genesis and Growth Characteristics. OtolNeurotol. 2015. https://doi. org/10.1097/MAO.0000000000000788.

18. Karajannis MA, Legault G, Hagiwara M, Giancotti FG, Filatov A, Derman A, Hochman T, Goldberg JD, Vega E, Wisoff JH, Golfinos JG, Merkelson A, Roland JT, et al. Phase II study of everolimus in children and adults with neurofibromatosis type 2 and progressive vestibular schwannomas. NeuroOncol. 2014; 16: 292-7.

19. Rubin JB, Gutmann DH. Neurofibromatosis type 1 - a model for nervous system tumour formation? NatRevCancer. 2005; 5: 557-64.

20. Grobmyer SR, Reith JD, Shahlaee A, Bush CH, Hochwald SN. Malignant Peripheral Nerve Sheath Tumor: molecular pathogenesis and current management considerations. JSurgOncol. 2008; 97: 340-9. https://doi.org/10.1002/ jso.20971.

21. Kroep JR, Ouali M, Gelderblom H, Le CA, Dekker TJ, Van GM, Hogendoorn PC, Hohenberger P. First-line chemotherapy for malignant peripheral nerve sheath tumor (MPNST) versus other histological soft tissue sarcoma subtypes and as a prognostic factor for MPNST: an EORTC soft tissue and bone sarcoma group study. AnnOncol. 2011; 22: 207-14.

22. Chang G. Multidrug resistance ABC transporters. FEBS Lett. 2003; 555: 102-5.

23. Borst P, Elferink RO. Mammalian ABC transporters in health and disease. Annu Rev Biochem. 2002; 71: 537-92. https://doi.org/10.1146/annurev.biochem.71.102301.093055.

24. Borst P, Schinkel AH. P-glycoprotein ABCB1: a major player in drug handling by mammals. J Clin Invest. 2013; 123: 4131-3. https://doi.org/10.1172/jci70430.

25. Franke RM, Gardner ER, Sparreboom A. Pharmacogenetics of drug transporters. Curr Pharm Des. 2010; 16: 220-30.

26. Hayashi H, Sugiyama Y. Bile salt export pump (BSEP/ $\mathrm{ABCB} 11)$ : trafficking and sorting disturbances. Curr Mol Pharmacol. 2013; 6: 95-103.

27. Klaassen CD, Aleksunes LM. Xenobiotic, bile acid, and cholesterol transporters: function and regulation. Pharmacol Rev. 2010; 62: 1-96. https://doi.org/10.1124/pr.109.002014.

28. Vasiliou V, Vasiliou K, Nebert DW. Human ATP-binding cassette (ABC) transporter family. HumGenomics. 2009; 3 : 281-90.

29. Juliano RL, Ling V. A surface glycoprotein modulating drug permeability in Chinese hamster ovary cell mutants. Biochim Biophys Acta. 1976; 455: 152-62.

30. Doyle LA, Yang W, Abruzzo LV, Krogmann T, Gao Y, Rishi AK, Ross DD. A multidrug resistance transporter from human MCF-7 breast cancer cells. ProcNatlAcadSciUSA. 1998; 95: 15665-70.

31. Aye IL, Keelan JA. Placental ABC transporters, cellular toxicity and stress in pregnancy. Chem Biol Interact. 2013; 203: 456-66. https://doi.org/10.1016/j.cbi.2013.03.007.

32. Hartz AM, Bauer B. ABC transporters in the CNS - an inventory. Curr Pharm Biotechnol. 2011; 12: 656-73.

33. Robillard KR, Hoque T, Bendayan R. Expression of ATPbinding cassette membrane transporters in rodent and human sertoli cells: relevance to the permeability of antiretroviral therapy at the blood-testis barrier. J Pharmacol Exp Ther. 2012; 340: 96-108. https://doi.org/10.1124/jpet.111.186916.

34. Brandt C, Bethmann K, Gastens AM, Loscher W. The multidrug transporter hypothesis of drug resistance in epilepsy: Proof-of-principle in a rat model of temporal lobe epilepsy. Neurobiol Dis. 2006; 24: 202-11. https://doi. org/10.1016/j.nbd.2006.06.014.

35. Peltonen S, Alanne M, Peltonen J. Barriers of the peripheral nerve. Tissue Barriers. 2013; 1: e24956. https://doi. org/10.4161/tisb.24956.

36. Shimizu F, Sano Y, Maeda T, Abe MA, Nakayama H, Takahashi R, Ueda M, Ohtsuki S, Terasaki T, Obinata M, Kanda T. Peripheral nerve pericytes originating from the blood-nerve barrier expresses tight junctional molecules and 
transporters as barrier-forming cells. J Cell Physiol. 2008; 217: 388-99. 10.1002/jcp.21508.

37. Sano Y, Shimizu F, Nakayama H, Abe M, Maeda T, Ohtsuki S, Terasaki T, Obinata M, Ueda M, Takahashi R, Kanda T. Endothelial cells constituting blood-nerve barrier have highly specialized characteristics as barrier-forming cells. Cell Struct Funct. 2007; 32: 139-47.

38. Scheffer GL, Maliepaard M, Pijnenborg AC, van Gastelen MA, de Jong MC, Schroeijers AB, van der Kolk DM, Allen JD, Ross DD, van der Valk P, Dalton WS, Schellens JH, Scheper RJ. Breast cancer resistance protein is localized at the plasma membrane in mitoxantrone- and topotecanresistant cell lines. Cancer Res. 2000; 60: 2589-93.

39. Jin Y, Bin ZQ, Qiang H, Liang C, Hua C, Jun D, Dong WA, Qing L. ABCG2 is related with the grade of glioma and resistance to mitoxantone, a chemotherapeutic drug for glioma. JCancer ResClinOncol. 2009; 135: 1369-76. https:// doi.org/10.1007/s00432-009-0578-4.

40. Faneyte IF, Kristel PM, Maliepaard M, Scheffer GL, Scheper RJ, Schellens JH, van de Vijver MJ. Expression of the breast cancer resistance protein in breast cancer. ClinCancer Res. 2002; 8: 1068-74.

41. Diestra JE, Condom E, Del Muro XG, Scheffer GL, Perez J, Zurita AJ, Munoz-Segui J, Vigues F, Scheper RJ, Capella G, Germa-Lluch JR, Izquierdo MA. Expression of multidrug resistance proteins P-glycoprotein, multidrug resistance protein 1 , breast cancer resistance protein and lung resistance related protein in locally advanced bladder cancer treated with neoadjuvant chemotherapy: biological and clinical implications. JUrol. 2003; 170: 1383-7. https:// doi.org/10.1097/01.ju.0000074710.96154.c9.

42. Nakayama K, Kanzaki A, Ogawa K, Miyazaki K, Neamati N, Takebayashi Y. Copper-transporting P-type adenosine triphosphatase (ATP7B) as a cisplatin based chemoresistance marker in ovarian carcinoma: comparative analysis with expression of MDR1, MRP1, MRP2, LRP and BCRP. IntJCancer. 2002; 101: 488-95. https://doi. org/10.1002/ijc.10608.

43. Tsunoda S, Okumura T, Ito T, Kondo K, Ortiz C, Tanaka E, Watanabe G, Itami A, Sakai Y, Shimada Y. ABCG2 expression is an independent unfavorable prognostic factor in esophageal squamous cell carcinoma. Oncology. 2006; 71: 251-8.

44. Shen B, Dong P, Li D, Gao S. Expression and function of ABCG2 in head and neck squamous cell carcinoma and cell lines. ExpTherMed. 2011; 2: 1151-7.

45. Bhatia P, Bernier M, Sanghvi M, Moaddel R, Schwarting R, Ramamoorthy A, Wainer IW. Breast cancer resistance protein (BCRP/ABCG2) localises to the nucleus in glioblastoma multiforme cells. Xenobiotica. 2012; 42: 74855. https://doi.org/10.3109/00498254.2012.662726.

46. Diestra JE, Scheffer GL, Catala I, Maliepaard M, Schellens JH, Scheper RJ, Germa-Lluch JR, Izquierdo MA. Frequent expression of the multi-drug resistance-associated protein
$\mathrm{BCRP} / \mathrm{MXR} / \mathrm{ABCP} / \mathrm{ABCG} 2$ in human tumours detected by the BXP-21 monoclonal antibody in paraffin-embedded material. JPathol. 2002; 198: 213-9. https://doi.org/10.1002/ path.1203

47. Slomiany MG, Dai L, Bomar PA, Knackstedt TJ, Kranc DA, Tolliver L, Maria BL, Toole BP. Abrogating drug resistance in malignant peripheral nerve sheath tumors by disrupting hyaluronan-CD44 interactions with small hyaluronan oligosaccharides. Cancer Res. 2009; 69: 4992-8.

48. Mo W, Zhang JT. Human ABCG2: structure, function, and its role in multidrug resistance. IntJBiochemMolBiol. 2012; 3: 1-27.

49. Ross DD, Nakanishi T. Impact of breast cancer resistance protein on cancer treatment outcomes. Methods MolBiol. 2010; 596: 251-90. https://doi. org/10.1007/978-1-60761-416-6_12.

50. Natarajan K, Xie Y, Baer MR, Ross DD. Role of breast cancer resistance protein (BCRP/ABCG2) in cancer drug resistance. BiochemPharmacol. 2012; 83: 1084-103.

51. Zhou S, Schuetz JD, Bunting KD, Colapietro AM, Sampath J, Morris JJ, Lagutina I, Grosveld GC, Osawa M, Nakauchi $\mathrm{H}$, Sorrentino BP. The ABC transporter Bcrp1/ABCG2 is expressed in a wide variety of stem cells and is a molecular determinant of the side-population phenotype. Nat Med. 2001; 7: 1028-34. https://doi.org/10.1038/nm0901-1028.

52. Dean M, Fojo T, Bates S. Tumour stem cells and drug resistance. Nat Rev Cancer. 2005; 5: 275-84. https://doi. org/10.1038/nrc1590.

53. Simon R, Mirlacher M, Sauter G. Immunohistochemical analysis of tissue microarrays. Methods Mol Biol. 2010; 664: 113-26. https://doi.org/10.1007/978-1-60761-806-5_12.

54. Bubendorf L, Nocito A, Moch H, Sauter G. Tissue microarray (TMA) technology: miniaturized pathology archives for high-throughput in situ studies. J Pathol. 2001; 195: 72-9. https://doi.org/10.1002/path.893.

55. Cordon-Cardo C, O'Brien JP, Casals D, Rittman-Grauer L, Biedler JL, Melamed MR, Bertino JR. Multidrug-resistance gene (P-glycoprotein) is expressed by endothelial cells at blood-brain barrier sites. Proc Natl Acad Sci U S A. 1989; 86: 695-8.

56. Cooray HC, Blackmore CG, Maskell L, Barrand MA. Localisation of breast cancer resistance protein in microvessel endothelium of human brain. Neuroreport. 2002; 13: 2059-63.

57. Chen Y, Agarwal S, Shaik NM, Chen C, Yang Z, Elmquist WF. P-glycoprotein and breast cancer resistance protein influence brain distribution of dasatinib. J Pharmacol Exp Ther. 2009; 330: 956-63. https://doi.org/10.1124/ jpet.109.154781.

58. de Vries NA, Zhao J, Kroon E, Buckle T, Beijnen JH, van Tellingen O. P-glycoprotein and breast cancer resistance protein: two dominant transporters working together in limiting the brain penetration of topotecan. Clin Cancer 
Res. 2007; 13: 6440-9. https://doi.org/10.1158/1078-0432. ccr-07-1335.

59. Polli JW, Olson KL, Chism JP, John-Williams LS, Yeager RL, Woodard SM, Otto V, Castellino S, Demby VE. An unexpected synergist role of P-glycoprotein and breast cancer resistance protein on the central nervous system penetration of the tyrosine kinase inhibitor lapatinib (N-\{3-chloro-4-[(3-fluorobenzyl)oxy]phenyl\}-6-[5(\{[2-(methylsulfonyl)ethyl]amino $\}$ methyl)-2-furyl $]-4-$ quinazolinamine; GW572016). Drug Metab Dispos. 2009; 37: 439-42. https://doi.org/10.1124/dmd.108.024646.

60. Dahlin A, Geier E, Stocker SL, Cropp CD, Grigorenko E, Bloomer M, Siegenthaler J, Xu L, Basile AS, Tang-Liu DD, Giacomini KM. Gene expression profiling of transporters in the solute carrier and ATP-binding cassette superfamilies in human eye substructures. Mol Pharm. 2013; 10: 650-63. https://doi.org/10.1021/mp300429e.

61. Huang L, Li X, Roberts J, Janosky B, Lin MH. Differential role of $\mathrm{P}$-glycoprotein and breast cancer resistance protein in drug distribution into brain, CSF and peripheral nerve tissues in rats. Xenobiotica. 2015; 45: 547-55. https://doi. org/10.3109/00498254.2014.997324.

62. Saito T, Zhang ZJ, Shibamori Y, Ohtsubo T, Noda I, Yamamoto T, Saito H. P-glycoprotein expression in capillary endothelial cells of the 7th and 8th nerves of guinea pig in relation to blood-nerve barrier sites. Neurosci Lett. 1997; 232: 41-4.

63. Saito T, Zhang ZJ, Ohtsubo T, Noda I, Shibamori Y, Yamamoto T, Saito H. Homozygous disruption of the mdrla P-glycoprotein gene affects blood-nerve barrier function in mice administered with neurotoxic drugs. Acta Otolaryngol. 2001; 121: 735-42.

64. Payne JM, Barton B, Ullrich NJ, Cantor A, Hearps SJ, Cutter G, Rosser T, Walsh KS, Gioia GA, Wolters PL, Tonsgard J, Schorry E, Viskochil D, et al. Randomized placebo-controlled study of lovastatin in children with neurofibromatosis type 1. Neurology. 2016; 87: 2575-84. https://doi.org/10.1212/wnl.0000000000003435.

65. Kalamarides M, Acosta MT, Babovic-Vuksanovic D, Carpen O, Cichowski K, Evans DG, Giancotti F, Hanemann $\mathrm{CO}$, Ingram D, Lloyd AC, Mayes DA, Messiaen L, Morrison H, et al. Neurofibromatosis 2011: a report of the Children's Tumor Foundation annual meeting. Acta Neuropathol. 2012; 123: 369-80. https://doi.org/10.1007/ s00401-011-0905-0.

66. Kim A, Dombi E, Tepas K, Fox E, Martin S, Wolters P, Balis FM, Jayaprakash N, Turkbey B, Muradyan N, Choyke PL, Reddy A, Korf B, et al. Phase I trial and pharmacokinetic study of sorafenib in children with neurofibromatosis type I and plexiform neurofibromas. Pediatr Blood Cancer. 2013; 60: 396-401. https://doi.org/10.1002/pbc.24281.

67. Miller SJ, Rangwala F, Williams J, Ackerman P, Kong $\mathrm{S}$, Jegga AG, Kaiser S, Aronow BJ, Frahm S, Kluwe L, Mautner V, Upadhyaya M, Muir D, et al. Large-scale molecular comparison of human schwann cells to malignant peripheral nerve sheath tumor cell lines and tissues. Cancer Res. 2006; 66: 2584-91. https://doi.org/10.1158/0008-5472. can-05-3330.

68. Spyra M, Kluwe L, Hagel C, Nguyen R, Panse J, Kurtz A, Mautner VF, Rabkin SD, Demestre M. Cancer stem cell-like cells derived from malignant peripheral nerve sheath tumors. PLoS One. 2011; 6: e21099. https://doi. org/10.1371/journal.pone.0021099.

69. Oda Y, Saito T, Tateishi N, Ohishi Y, Tamiya S, Yamamoto $\mathrm{H}$, Yokoyama R, Uchiumi T, Iwamoto $\mathrm{Y}$, Kuwano M, Tsuneyoshi M. ATP-binding cassette superfamily transporter gene expression in human soft tissue sarcomas. Int J Cancer. 2005; 114: 854-62. https://doi.org/10.1002/ ijc.20589.

70. Neradil J, Veselska R. Nestin as a marker of cancer stem cells. Cancer Sci. 2015; 106: 803-11. https://doi. org/10.1111/cas.12691.

71. Jessen WJ, Miller SJ, Jousma E, Wu J, Rizvi TA, Brundage ME, Eaves D, Widemann B, Kim MO, Dombi E, Sabo J, Hardiman Dudley A, Niwa-Kawakita M, et al. MEK inhibition exhibits efficacy in human and mouse neurofibromatosis tumors. J Clin Invest. 2013; 123: 340-7. https://doi.org/10.1172/jci60578.

72. Agarwal S, Hartz AM, Elmquist WF, Bauer B. Breast cancer resistance protein and P-glycoprotein in brain cancer: two gatekeepers team up. Curr Pharm Des. 2011; 17: 2793-802.

73. Jablonski MR, Markandaiah SS, Jacob D, Meng NJ, Li K, Gennaro V, Lepore AC, Trotti D, Pasinelli P. Inhibiting drug efflux transporters improves efficacy of ALS therapeutics. Ann Clin Transl Neurol. 2014; 1: 996-1005. https://doi. org/10.1002/acn3.141.

74. Kirkinezos IG, Hernandez D, Bradley WG, Moraes CT. An ALS mouse model with a permeable blood-brain barrier benefits from systemic cyclosporine A treatment. J Neurochem. 2004; 88: 821-6.

75. Lin F, de Gooijer MC, Roig EM, Buil LC, Christner SM, Beumer JH, Wurdinger T, Beijnen JH, van Tellingen $\mathrm{O}$. $\mathrm{ABCB} 1, \mathrm{ABCG} 2$, and PTEN determine the response of glioblastoma to temozolomide and ABT-888 therapy. Clin Cancer Res. 2014; 20: 2703-13. https://doi. org/10.1158/1078-0432.ccr-14-0084.

76. Bai RY, Staedtke V, Wanjiku T, Rudek MA, Joshi A, Gallia GL, Riggins GJ. Brain Penetration and Efficacy of Different Mebendazole Polymorphs in a Mouse Brain Tumor Model. Clin Cancer Res. 2015; 21: 3462-70. https:// doi.org/10.1158/1078-0432.ccr-14-2681.

77. Morfouace M, Cheepala S, Jackson S, Fukuda Y, Patel YT, Fatima S, Kawauchi D, Shelat AA, Stewart CF, Sorrentino BP, Schuetz JD, Roussel MF. ABCG2 Transporter Expression Impacts Group 3 Medulloblastoma Response to Chemotherapy. Cancer Res. 2015; 75: 3879-89. https://doi. org/10.1158/0008-5472.can-15-0030.

78. Zander SA, Sol W, Greenberger L, Zhang Y, van Tellingen O, Jonkers J, Borst P, Rottenberg S. EZN-2208 
(PEG-SN38) overcomes ABCG2-mediated topotecan resistance in BRCA1-deficient mouse mammary tumors. PLoS One. 2012; 7: e45248. https://doi.org/10.1371/journal. pone. 0045248 .

79. Imbert F, Jardin M, Fernandez C, Gantier JC, Dromer F, Baron G, Mentre F, Van Beijsterveldt L, Singlas E, Gimenez F. Effect of efflux inhibition on brain uptake of itraconazole in mice infected with Cryptococcus neoformans. Drug Metab Dispos. 2003; 31: 319-25.

80. Joosen MJ, van der Schans MJ, van Dijk CG, Kuijpers WC, Wortelboer HM, van Helden HP. Increasing oxime efficacy by blood-brain barrier modulation. Toxicol Lett. 2011; 206: 67-71. https://doi.org/10.1016/j.toxlet.2011.05.231.

81. van Vliet EA, van Schaik R, Edelbroek PM, Voskuyl RA, Redeker S, Aronica E, Wadman WJ, Gorter JA. Regionspecific overexpression of P-glycoprotein at the bloodbrain barrier affects brain uptake of phenytoin in epileptic rats. J Pharmacol Exp Ther. 2007; 322: 141-7. https://doi. org/10.1124/jpet.107.121178.

82. van Vliet EA, van Schaik R, Edelbroek PM, Redeker S, Aronica E, Wadman WJ, Marchi N, Vezzani A, Gorter JA. Inhibition of the multidrug transporter P-glycoprotein improves seizure control in phenytoin-treated chronic epileptic rats. Epilepsia. 2006; 47: 672-80. https://doi. org/10.1111/j.1528-1167.2006.00496.x.

83. Jo VY, Fletcher CD. WHO classification of soft tissue tumours: an update based on the 2013 (4th) edition. Pathology. 2014; 46: 95-104. https://doi.org/10.1097/ PAT.0000000000000050.

84. Bovee JV, van den Broek LJ, de Boer WI, Hogendoorn PC. Expression of growth factors and their receptors in adamantinoma of long bones and the implication for its histogenesis. JPathol. 1998; 184: 24-30. 